\title{
Response of Some Sugar Beet Varieties to Harvesting Dates and Foliar Application of Boron and Zinc in Sandy Soils
}

Hanan Y. Mohamed and M.A.T. Yasin*

Sugar Crops Res. Inst., Agric. Res. Center, Giza and *Agron. Dept.,Fac.Agric., Zagazig Univ., Sharkia, Egypt.

\begin{abstract}
7 TE PRESENT investigation was carried out at the experimental farm, El-Khattara region, Fac. Agric. Zagazig University, Sharkia Governorate , Egypt during 2010/2011 and 2011/2012 seasons to investigate the effect of micronutrients (control, B , $\mathrm{Zn}$ and their combinations) on four sugar beet varieties (Panther and Des 9003) multigerm, also ( LP15 and Sibel ) monogerm under three harvesting dates (180, 195 and 210) days from sowing. A split-split plot design with three replications was used. Harvesting dates were allocated in the main plots, foliar applications of micronutrients were assigned in the sub plots while, sugar beet varieties were distributed in the subsub plots. The results revealed that delaying harvesting date from 180 to 195 and 210 days significantly increased quality parameters, i.e. sucrose, purity and extractability percentages as well as productivity traits (root and sugar yields) in the two growing seasons. The varieties significantly differed in all studieds traits in the two growing seasons. Foliar spray with $\mathrm{B}$ and $\mathrm{Zn}$ had significant effects on all studies traits in both seasons, except for root diameter $(\mathrm{cm})$ in both seasons and juice purity\% in $1^{s t}$ season only. Sibel had the higher root yield in both seasons for all dates of harvest.This applied also to sugar exception of one of the dates of harvest in the second season. Delaying the harvesting date to 210 days after sowing compared to 180 days significantly increased yields of root and sugar (ton/ fed) in both seasons. The foliar application with $\mathrm{B}$ and $\mathrm{Zn}$ under the three harvesting dates insignificantly affected all traits studied.
\end{abstract}

Keywords: Harvesting date, B, Zn, Sugar beet varieties, Extractability \%.

Expanding cultivation of sugar beet (Beta vulgaris L.) on the newly reclaimed lands should be hardly pushed to increase the sugar crop area, consequently increased local production of sugar. Selecting the proper time of harvesting is necessary to obtain the maximum yield from the mentioned promising area. Many investigators reported that delaying harvest date of sugar beet up to 200 or 210 days after sowing improved significantly the individual root characters and juice quality, as well as increased significantly root and sugar yields /fed (Abd El-Razek, 2006; Mahmoud et al., 2008 El-Sheikh et al., 2009; Yousef \&Abdel-Mottaleb, 2009 and Enan et al., 2011). On the other hand, Al -Sayed et al. (2012) found that delaying harvest date up to 210 days from sowing gave the highest root dimension (length and diameter), root yield /fed, 
the best quality (sucrose\%, and T.S.S.) and root and sugar yields compared with harvesting at 180 days from sowing.

Boron is essential for providing sugars, which are needed for root growth in all plants. In this connection, Cook \& Scott (1993) mentioned that boron is the most important of the trace elements needed by sugar beet because, without an adequate supply, the yield and quality is very depressed. Gobarah \& Mekki (2005) fertilized sugar beet with four levels of boron (zero, 1, 1.5 and $2 \mathrm{~kg} / \mathrm{fed}$ ). They found that increasing boron rate up to $1.5 \mathrm{~kg} / \mathrm{acre}$ increased root length, diameter and root yield however, increasing boron fertilizer up to $2.0 \mathrm{~kg} / \mathrm{acre}$ resulted in the highest sucrose, recoverable sucrose and juice purity percentages as well as recoverable sugar yield. Kristek et al. (2006) showed that root yield was higher by $13.6 \mathrm{t} / \mathrm{ha}(19.4 \%)$, sugar concentration higher by $1.46 \%$ and sugar yield higher by 3.15 t/ha (39.5\%). Allen \& Pilbeam (2007) stated that boron increases the rate of transport of sugars (which are produced by photosynthesis in mature plant leaves) to actively growing regions and also in developing roots. Abo El-Hamd \& Esmail (2008) mentioned that increasing B levels from 100 to $200 \mathrm{ppm}$ as boric acid/fed significantly improved root length, root diameter, root fresh weight/plant and sugar yield/fed. Hellal et al. (2009) found that application of boron significantly improved the yield of root and above ground growth and nutrient contents. Enan (2011) stated that highest values of root diameter, root fresh weight, root, top and sugar yields/fed, as well as sucrose $\%$ were obtained with increasing boron application to $200 \mathrm{ppm}$. Mohammed \& Asghharipour (2011) and Armin \& Asgharipour (2012) found that B application increased root yield and sucrose concentration, while decreased $\mathrm{K}, \mathrm{Na}, \alpha-$ amino $\mathrm{N}$ and molasses sugar compared with those of the control. Mohamed et al. (2012) obtained that foliar application with boron significantly increased root length, yields of top, root and sugar/ fed, as well as $\mathrm{Na} \%$ in both seasons.

Zinc is essential element for crop production, also it required in the carbonic enzyme which present in all photosynthetic tissues, and required for chlorophyll biosynthesis. In general, zinc have main role in synthesis of proteins, enzyme activating, oxidation and revival reactions and metabolism of carbohydrates (Alloway, 2008 and Mousavi et al., 2013). Zinc treatments affected root and sugar yields at a $95 \%$ confidence level in the first of three years and affected root yield at a $90 \%$ confidence level in the third year. Applied ZnSO4 in the seed row at $6 \mathrm{lb} / \mathrm{acre}(\mathrm{Zn}$ at $2 \mathrm{lb} / \mathrm{acre})$ treatment producing a root yield that exceeded the check by 4.2 tons/acre (Stevens \& Mesbah, 2004). El-Hawary (1994) and ElGeddawy et al. (2007), cleared that application of zinc element alone or in combination with boron element significantly resulted in higher values of root length and diameter, top yield/fed compared with those recorded by unfertilized or applied with boron only. Application of boron alone or in combination with zinc produced higher root fresh weight/plant, sugar recovery $\%$ as well as root and sugar yields/fed compared with those recorded by the unfertilized or applied with zinc alone. Moustafa et al. (2011) showed foliar spray with the mixture of $\mathrm{Zn}, \mathrm{Mn}$ and Fe exhibited the best treatment, where it gave the highest values of most traits under study.

Egypt. J. Agron. 35, No. 2 (2013) 
Sugar beet seeds sown in Egypt are imported and hence beet varieties should be evaluated under the Egyptian conditions to select the best varieties in respect to yield and quality traits. Aly (2006) found that Marathon variety had almost the best values of root length, , diameter and root fresh weight, as well as root and sugar yields/fed. On the other hand, Kawimera variety was the highest one in sucrose\%, extractable sugar and extractability percentages. Azzazy et al. (2007), El-Sheikh et al. (2009) and Enan et al.(2009) found that sugar beet varieties differed significantly in all studied traits except TSS\% in both seasons. Sugar yield in the $1^{s t}$ season Farida variety gave a significant increase for sugar yield, juice quality( TSS, sucrose and purity\% ).While it recorded the lowest values of impurities (Na, K and N\%). Mohamed et al. (2012) declard that the differences between sugar beet varieties were significant in root dimension( root and sugar yields/fed), sucrose $\%$ and $\alpha$-amino N. Abd El-Aal et al. (2010) revealed that significant variation in yield productivity and root quality among sugar beet varieties. Kawemira and Gloria varieties gave the highest sugar yield followed by Nejma, on the other hand Lola exhibited the lowest sugar yield. Oscar poly, Carola, Raspoly, Kawemera and Mont Bianko were more response to added nitrogen fertilizer.

The present investigation aimed to find out the relative effect of three harvesting dates and foliar application of micro nutrients (boron and zinc) on yield and its quality of four sugar beet varieties.

\section{Materials and Methods}

Two field experiments were conducted the experimental farm, El-Khattra, Fac. Agric., Zagazig University, Sharkia Governorate, Egypt during 2010/2011 and 2011/2012 seasons to study the performance of four sugar beet varieties (Panther and Des 9003) multigerm seeds and ( LP15 and Sibel) monogerm seeds to foliar application of micronutrients ( control, boron, zinc and combination of them) under three harvesting dates (180, 200 and 210 days from sowing) . Boron as boric acid $\left(\mathrm{H}_{3} \mathrm{Bo}_{4}\right)$ and zinc as zinc sulfate $\left(\mathrm{ZnSO}_{4}\right)$ at rates $0.01 \%$ and $0.03 \%$, respectively were sprayed twice i.e. 45 and 75 days from planting.

Physical and chemical properties of the experimental soil site are presented in Table 1 that carried out according to Page (1982). Metrological parameters of the experimental sites in Table 2 .

The preceding crop was tomato in both seasons. A split-split plot design with three replications was used. Harvesting dates were allocated in the main plots, foliar applications of micronutrients were assigned in the sub plots while, Sugar beet varieties were allocated in the sub-sub plot. 
TABLE 1. Chemical and physical properties of the experimental soil ( 2010/2011 and 2011/2012 seasons) .

\begin{tabular}{|l|c|c|}
\hline Physical properties: & $\mathbf{2 0 1 0 / 2 0 1 1}$ & $\mathbf{2 0 1 1 / 2 0 1 2}$ \\
\hline Sand & 94.8 & 94.3 \\
\hline Silt & 2.8 & 3.6 \\
\hline Clay & 2.4 & 2.1 \\
\hline Texture & Sandy & Sandy \\
\hline Chemical properties : & & \\
\hline Organic matter $(\%)$ & 0.06 & 0.08 \\
\hline Available N (ppm) & 11.98 & 10.13 \\
\hline Available P $(\mathrm{ppm})$ & 3.90 & 3.30 \\
\hline Available K (ppm) & 66.25 & 64.10 \\
\hline Available Zn $(\mathrm{ppm})$ & 2.40 & 2.22 \\
\hline Available B $(\mathrm{ppm})$ & 0.32 & 0.30 \\
\hline Available Fe (ppm) & 4.32 & 4.20 \\
\hline CaCo $_{3}(\%)$ & 0.24 & 0.26 \\
\hline Ph & 8.12 & 8.15 \\
\hline E.C.(dsm $\left.{ }^{-1}\right)$ & 1.99 & 2.06 \\
\hline
\end{tabular}

TABLE 2. Metrological parameters of the experimental sites .

\begin{tabular}{|l|c|c|c|c|c|c|c|c|c|c|}
\hline \multirow{3}{*}{ Months } & \multicolumn{4}{|c|}{$\mathbf{2 0 1 0 / 2 0 1 1}$} & \multicolumn{4}{|c|}{$\mathbf{2 0 1 1 / 2 0 1 2}$} \\
\cline { 2 - 11 } & $\begin{array}{c}\text { Max. } \\
\text { temp. } \\
\text { C }\end{array}$ & $\begin{array}{c}\text { Min. } \\
\text { temp. } \\
\text { C }\end{array}$ & $\begin{array}{c}\text { R.H. } \\
(\boldsymbol{\%})\end{array}$ & $\begin{array}{c}\text { Rain } \\
\text { fall } \\
(\mathbf{m m})\end{array}$ & Air speed & $\begin{array}{c}\text { Max. } \\
\text { temp. } \\
\text { C }\end{array}$ & $\begin{array}{c}\text { Min. } \\
\text { temp. } \\
\text { C }\end{array}$ & $\begin{array}{c}\text { R.H. } \\
(\boldsymbol{\%})\end{array}$ & $\begin{array}{c}\text { Rain fall } \\
(\mathbf{m m})\end{array}$ & Air speed \\
\hline Nov. & 24.8 & 13.8 & 63 & 8.8 & 6 & 24.0 & 14.0 & 60 & 8.2 & 5 \\
\hline Dec. & 20.0 & 10.5 & 71 & 6.8 & 7 & 20.0 & 10.0 & 69 & 8.6 & 7 \\
\hline Jan. & 18.9 & 9.2 & 62 & 8.4 & 10 & 19.0 & 9.6 & 65 & 6.0 & 8 \\
\hline Febr. & 20.4 & 10.0 & 57 & 3.9 & 8 & 21.0 & 11.0 & 55 & 1.1 & 5 \\
\hline Mar. & 23.4 & 11.9 & 54 & 6.0 & 8 & 25 & 12.4 & 55 & 4.6 & 9 \\
\hline April & 28.2 & 15.0 & 49 & 2.0 & 9 & 29 & 16.2 & 50 & 0.4 & 10 \\
\hline May & 32.0 & 17.9 & 48 & 1.2 & 9 & 33.2 & 18.4 & 45 & 0.0 & 7 \\
\hline
\end{tabular}

Plot area was $12 \mathrm{~m}^{2}$ including five rows of $60-\mathrm{cm}$ width and 4-m long. Thinning was done after 45 days from planting to obtain one plant/hill (35000 plans/fed). Phosphorus fertilizer was added during seed bed preparation at the rate of $30 \mathrm{~kg} \mathrm{P}_{2} \mathrm{O}_{5} / \mathrm{fed}$, in the form of calcium superphosphate $\left(15.5 \% \mathrm{P}_{2} \mathrm{O}_{5}\right)$, while potassium fertilization was applied at the rate of $48 \mathrm{~kg} \mathrm{~K}_{2} \mathrm{O} / \mathrm{fad}$, as potassium sulphate $\left(48 \% \mathrm{~K}_{2} \mathrm{O}\right)$ in the two equal doses the first at seed bed preparation and the second after thinning. Nitrogen fertilizer was applied in the form of ammonium sulphate $(20.5 \% \mathrm{~N})$ in four equal doses, the first was applied after thinning and the others were applied at 2-weeks interval. Sugar beet was planted at distance of $20 \mathrm{~cm}$ in the $2^{\text {nd }}$ week of November in both seasons .Other agricultural practices were applied as recommended for growing sugar beet.

Egypt. J. Agron. 35, No. 2 (2013) 
At harvest, the three guarded central rows of each plot were harvested to estimate the following traits from random five plants:

Growth traits

Root length (cm).

Root diameter $(\mathrm{cm})$. .

Sugar beet yields (ton/fed)

The above mentioned was calculated by using a bulk sample which included all sugar beet plants of the three central rows of each plot $\left(7.2 \mathrm{~m}^{2}\right)$

Root yield (ton/fed).

Sugar yield (ton/fed) was calculated using the following equation:

Sugar yield $($ ton $/$ fed $)=$ Root yield $x$ sugar extraction $\%$.

\section{Quality traits}

Juice quality and some technological parameters were determined using an automatic French system (HYCEL).

1. Sucrose percentage (Pol. \%) was polarimetrically determined on a lead acetate extract of fresh macerated root according to the method of Le-Docte (1927).

2. Impurities ( $\mathrm{K}, \mathrm{Na}$ and $\alpha$-amino nitrogen) were determined in the digested extract of root dry matter as follows:

2.1 Sodium and Potassium percentages were determined using the Flame photometer according to A.O.A.C (2005).

2.2. $\alpha$-amino nitrogen was determined (Hydrindnation method) according to Carruthers et al. (1962).

3. Purity percentage: Purity, sugar lost in molasses and extractable sugar (rendement or recovery) percentages were calculated according to the following formulas:

-Purity \% = $99.36-14.27(\mathrm{~V} 1+\mathrm{V} 2+\mathrm{V} 3) / \mathrm{V} 4$ (Devillers, 1988)

-Sugar lost in molasses $(\mathrm{SLM} \%)=0.14(\mathrm{~V} 1+\mathrm{V} 2)+0.25(\mathrm{~V} 3)+0.50$ (Devillers, 1988).

-Sugar extraction \% = pol\% - SLM\% - 0.6 (Dexteret al., 1967).

-Extractability $\%=$ Sugar extraction/ pol\%

where: $\mathrm{V}_{1}=$ Sodium, $\mathrm{V}_{2}=$ Potassium, $\mathrm{V}_{3}=\alpha$-amino nitrogen, $\mathrm{V}_{4}=\mathrm{Pol} \%($ sucrose $\%)$

The collected data were statistically analyzed according to Snedecor \& Cochran (1981). Treatment means were compared using L.S.D at 5\% level of probability

\section{Effect of harvesting dates}

\section{Results and Discussion}

Data in Table 3 evidently showed that delay harvest from 180 to 210 days after sowing significantly influenced all the studied characters, except root length (cm) and sugar extraction $\%$ in the $1^{\text {st }}$ season and root diameter in the $2^{\text {nd }}$ season. Delaying harvest date to 210 days after sowing increased yields of root and 
sugar by $31.28 \%$ and $39.72 \%$ in the $1^{\text {st }}$ season as well as 20.43 and 22.67 in the $2^{\text {nd }}$ season, respectively. These results could be interpreted to the effect of the prevailing climatic factors, in particular temperature on growth, photosynthesis and respiration (Table 2). These results are in a good line with those obtained by Yousef \& Abdel-Mottaleb (2009) and Enan et al. (2011).

\section{Performance of sugar beet varieties}

Data given in Table 4 show that the differences among the examined varieties i.e. Panther, Des 9003, LP15 and Sibel were statistically significant with respect to all studied traits in both seasons. It's worth to mention that difference between monogerm varieties Des 9003 and LP15, and also multigerm beet varieties don't reach to the significant level in root diameter in the first season only. Sugar beet variety Sibel produced the highest values of sugar extraction, purity and extractability percentages, as well as lowest $\alpha$-amino Nand SLM percentages in both seasons. The differences among sugar beet varieties under study could be due to the variation in the genes make up and their response to the environmental condition. The differences among sugar beet varieties were found by Osman et al. (2003), Azzazy et al. (2007), El-Sheikh et al. (2009), Enan et al. (2009) and Abd El-Aal et al. (2010).

\section{Effect of micronutrients foliar application}

The collected data in Table 5 pointed out that using combination with boron and zinc as foliar application significantly increased sucrose, sugar extraction and extractability $\%$ while potassium $\%$ decreased in the $2^{s t}$ season .The quality of sugar beets improved significantly more by using $\mathrm{Zn}$ and $\mathrm{B}$ fertilizer in combination than separately in both seasons. Foliar application by B and Zn separately significantly increased yields of root and sugar (ton/ fed) in the $2^{\text {nd }}$ and $1^{\text {st }}$ seasons, respectively,as reported by Armin \& Asgharipour (2012) who found reported boron application increased root yield and sucrose concentration by $12.12 \%$ and $26.35 \%$, respectively, decreasing $\mathrm{K}+, \mathrm{Na}+$, -amino- $\mathrm{N}$ and molasses sugar compared with those of the control. Foliar application by B combined to $\mathrm{Zn}$ significantly decreased yields of root and sugar in both seasons, this may be attributed to antagonism effect between B and Zinc as reported by Tyksinski (1993) who found reported antagonism effect between $\mathrm{B}, \mathrm{Zn}, \mathrm{Cu}$ and $\mathrm{Mo}$ in Lettuce leaves. Data also showed that using B as foliar application alone or combined to $\mathrm{Zn}$ significantly increased $\alpha$-amino $\mathrm{N}$ compared to $\mathrm{Zn}$ alone in both seasons, this may be due to $\mathrm{N}$-Rase activity which was markedly increased with adding B as reported by Shen et al. (1993) in Rape plants. These results are in accordance with that reported by El-Hawary (1994), Al-Mohamad \& AlGeddawy (2001) and El-Geddawy et al. (2007). 


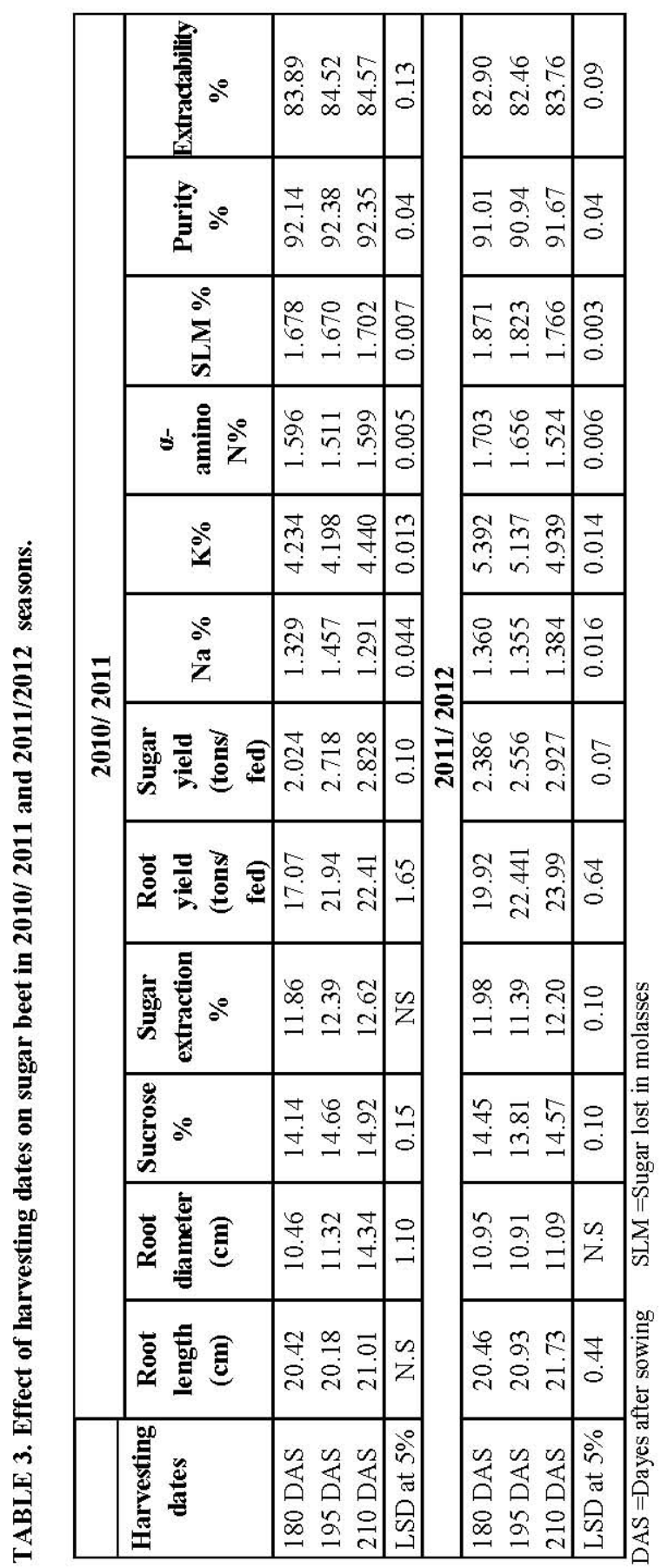

Egypt. J. Agron. 35, No. 2 (2013) 


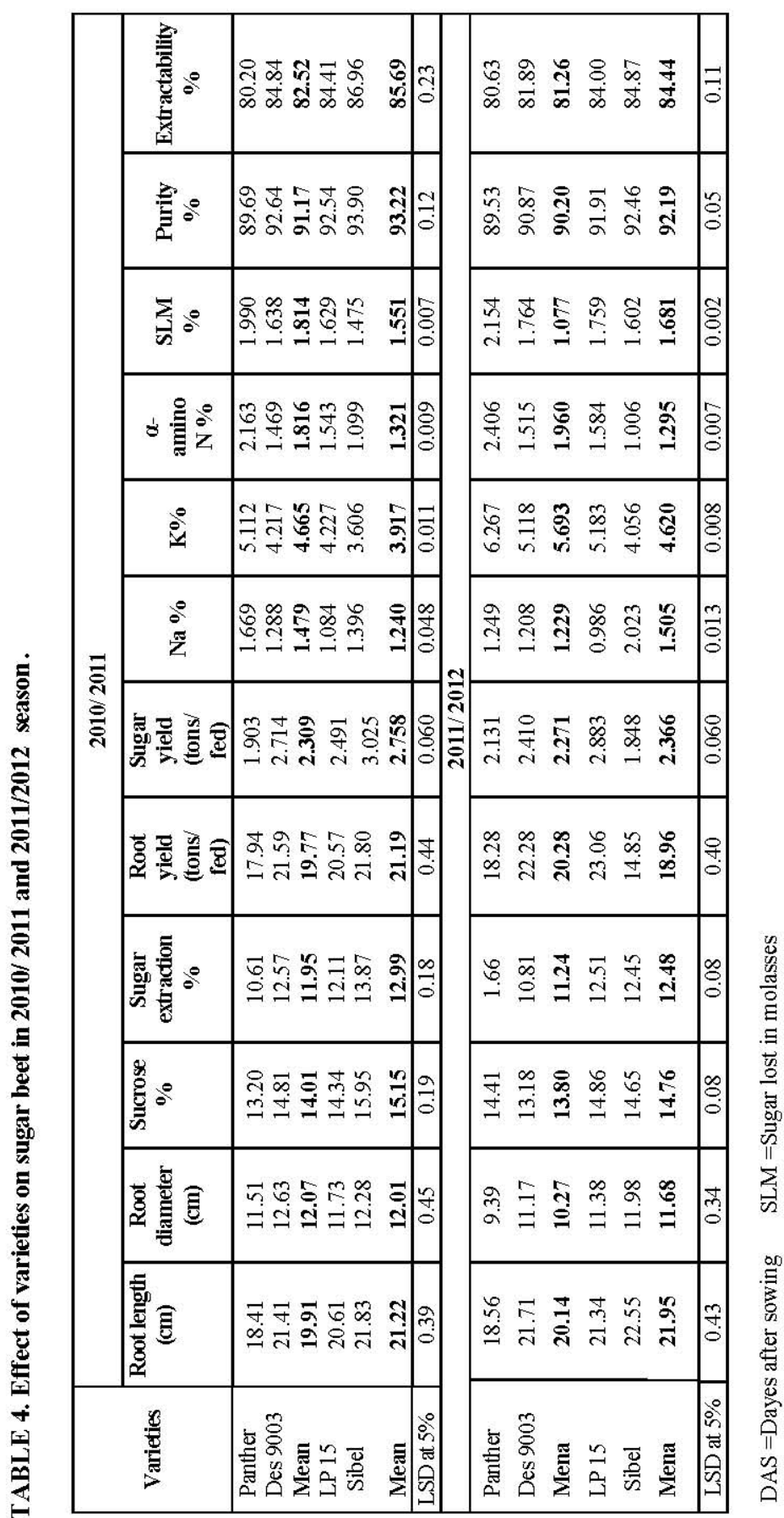




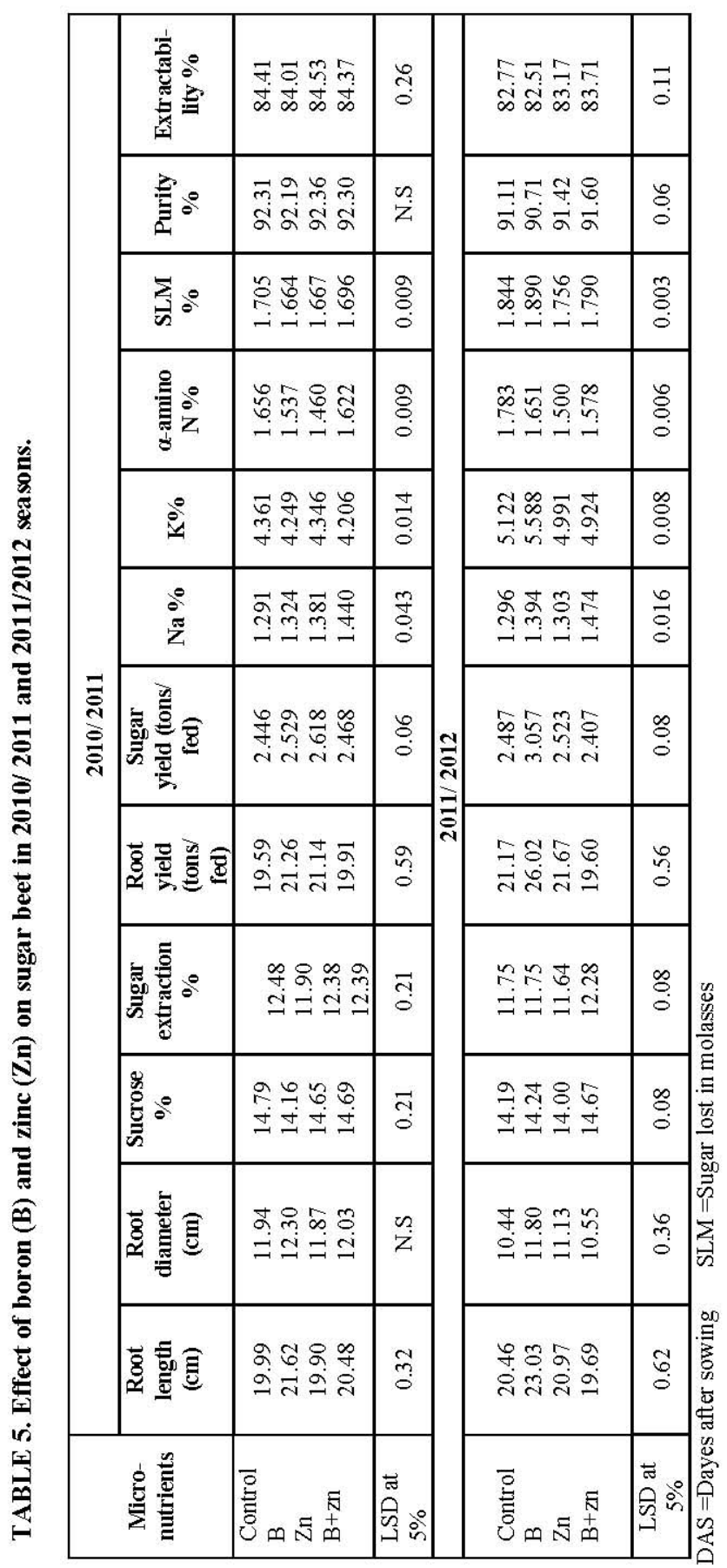

Egypt. J. Agron. 35, No. 2 (2013) 
Effect of the interactions between harvesting dates and micronutrients

Data in Tables 6 ( $\mathrm{a}$ and $\mathrm{b}$ ) and Fig. 1 and 2 indicated that the effect of the interaction between harvesting dates and foliar application of micronutrients, i.e. Boron and Zinc alone or in mixture was significant for all studied traits in both seasons. Foliar application with Boron and harvesting 210 days sowing (DAS) gave the highest root yield (ton/fed) in both season. in Table 6 a the highest root yield 24,19 tons per fed obtained with the latest harvest date and the application of B, compared with the lowest yield 15,5 tons per fed obtained with the earliest date of harvest and no foliar application, the effect of B in the best treatment was relatively low 22,18 tons per fed being obtained with the last harvest date without application of $\mathrm{B}$ which means that $\mathrm{B}$ contribution in the best treatment (last harvest date and application of B) brought the highest root yield (ton/fed) by 8.3\%.This treatment had also effects on sugar yield (ton/fed) but it gave the highest sugar yield (3.12) ton/fed only in the $2^{\text {nd }}$ season. It also gave the lowest sodium percentage in the $2^{\text {nd }}$ season only, that for boron is essential for growth and development. It is in highest demand during periods of rapid cell division and expansion playing a key role in cell wall development. Boron is only transported in the xylem and thus deficiency appears in the youngest leaves (Crop Nutrition).

Effect of the interaction between harvesting dates and sugar beet varieties

Data in Tables 7 ( $a$ and b) and Fig. 3 and 4 indicated that all of studied traits significantly affected by interaction between harvesting dates and varieties, except root length and root diameter in the $1^{\text {st }}$ and $2^{\text {nd }}$ seasons, respectively . It is worth to mention that harvesting Sibel sugar beet variety after 120 days from sowing gave the highest yields of root and sugar (ton/ fed) in both seasons., It gave also the highest sucrose and extractability percentages but in $1^{s t}$ season only. It was also the best for lowest potassium $(\mathrm{K})$ and $\alpha$-amino $\mathrm{N}$ in the $2^{\text {nd }}$ season only.The differences among sugar beet varieties under study could be due to the variation in the gene make up and their response to the environmental condition. Some of sugar beet genotypes have been promoted as high sugar content genotypes adapted for early harvest. Large genotype differences in crown tissue production (Halvorson et al., 1978 and Halvorson \& Hartman, 1980) and development rate may cause quality differences between genotypes and thus require different harvesting strategies.

Effect of the interaction between sugar beet varieties and micronutreints

Data in Tables 8 (a and b) and Fig. 5 and 6 indicated that studied traits were significantly affected by interaction between sugar beet varieties and application of boron and, zinc separately or mixed in both seasons. It is clear that Sibel variety $\mathrm{B}$ treated with foliar application gave the highest yields of root and sugar (tons/ fed), The highest sugar extraction and extractability percentages was recorded in both seasons for Sibel sugar beet variety treated with foliar application of a mixture of $\mathrm{B}$ and $\mathrm{Zn}$. The defference of varietal response to foliar application of boron and zinc may be mainly attributed to gen make up influences.

Egypt. J. Agron. 35, No. 2 (2013) 


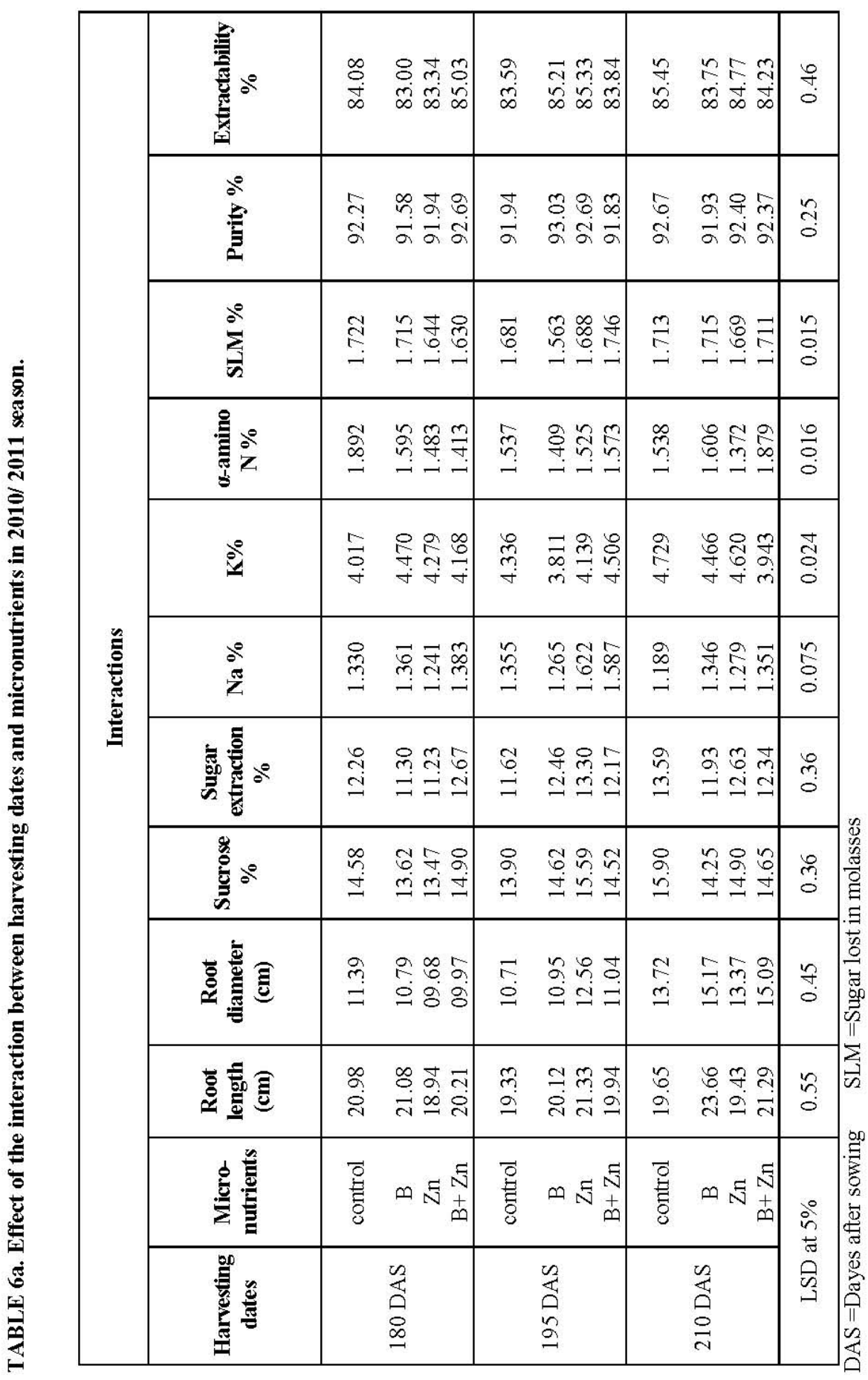




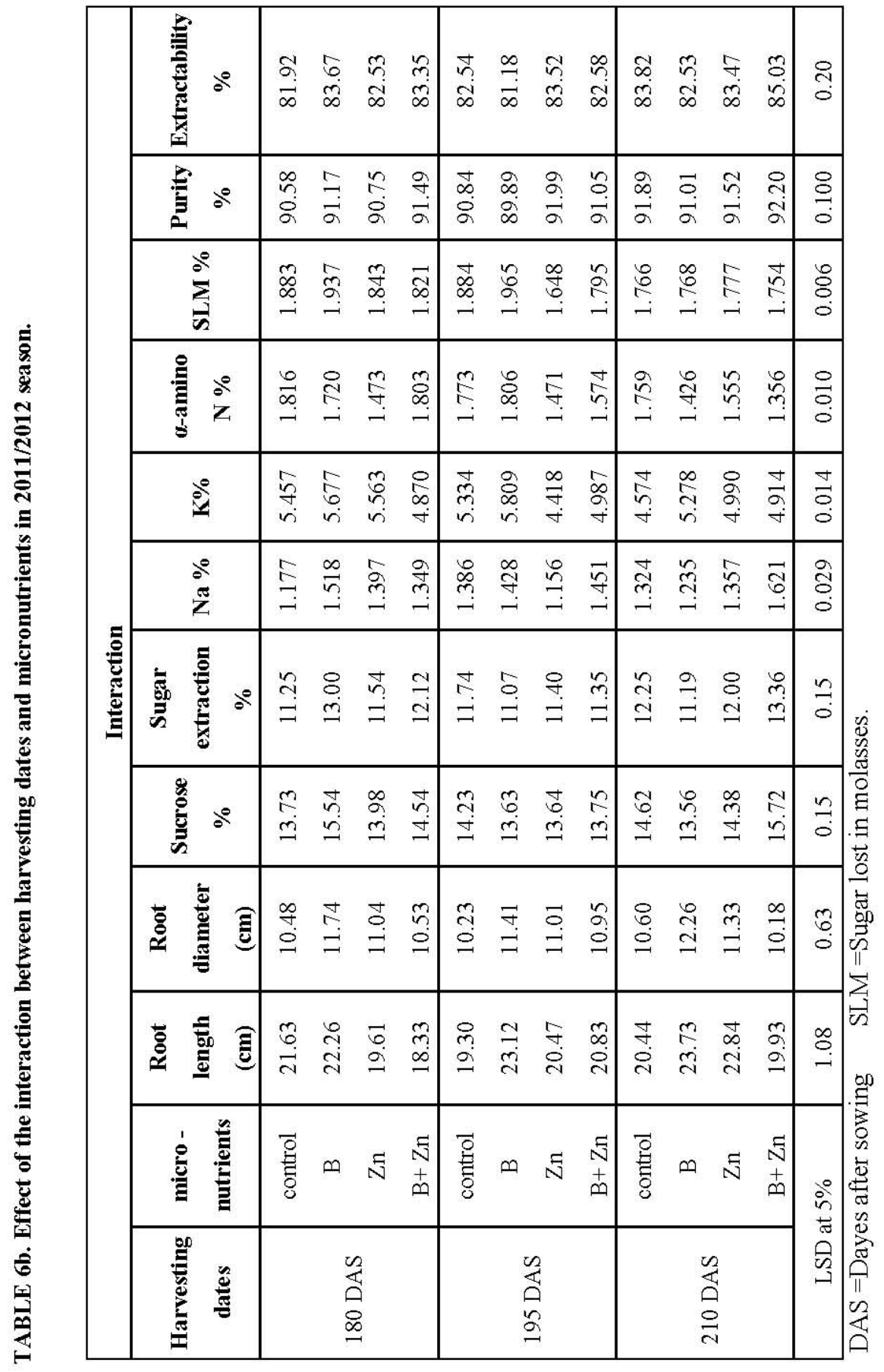

Egypt. J. Agron. 35, No. 2 (2013) 

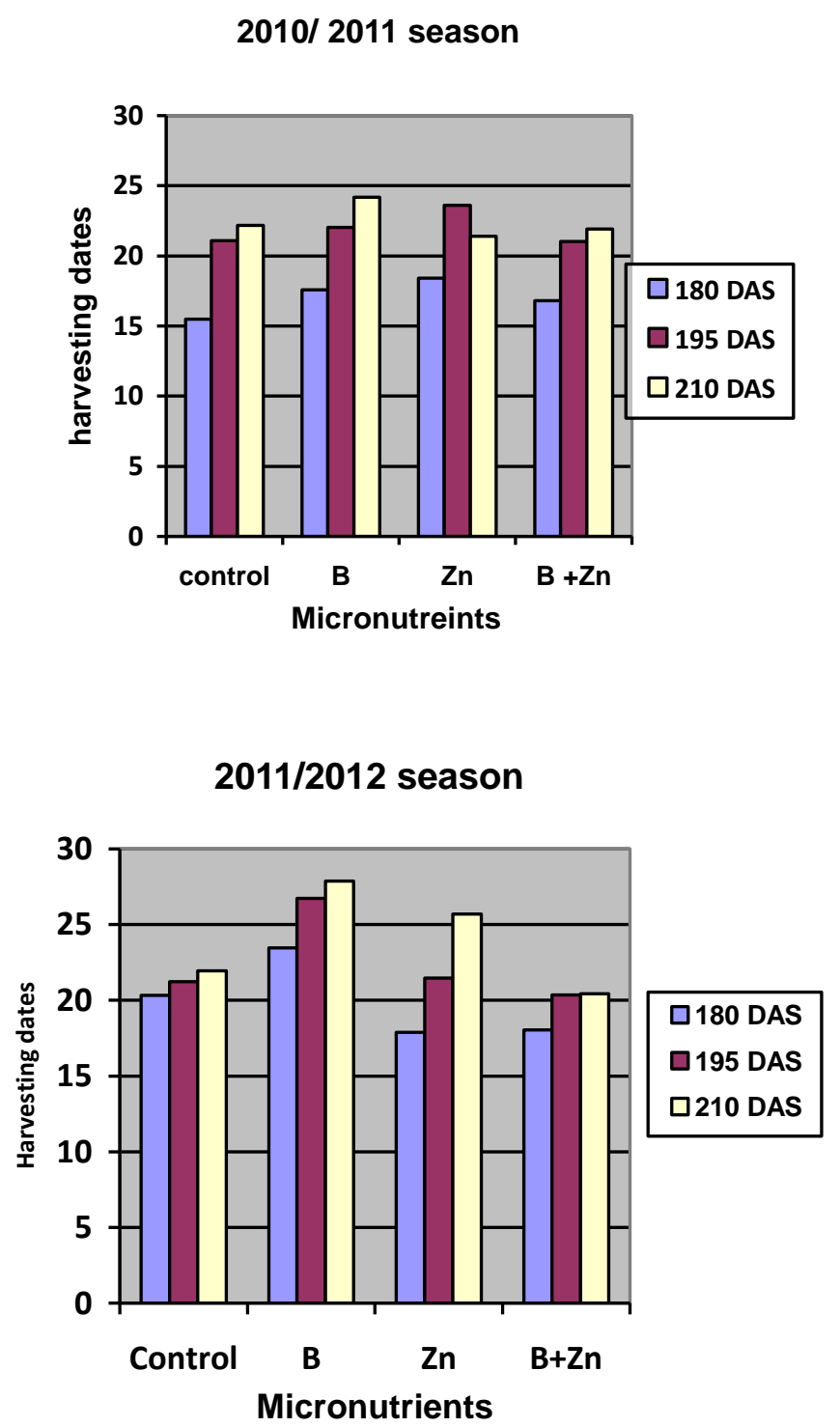

Fig. 1. Effect of the interaction between harvesting dates and micronutrients on root yield (ton/ fed) in 2010/ 2011 and 2011/ 2012 seasons . 

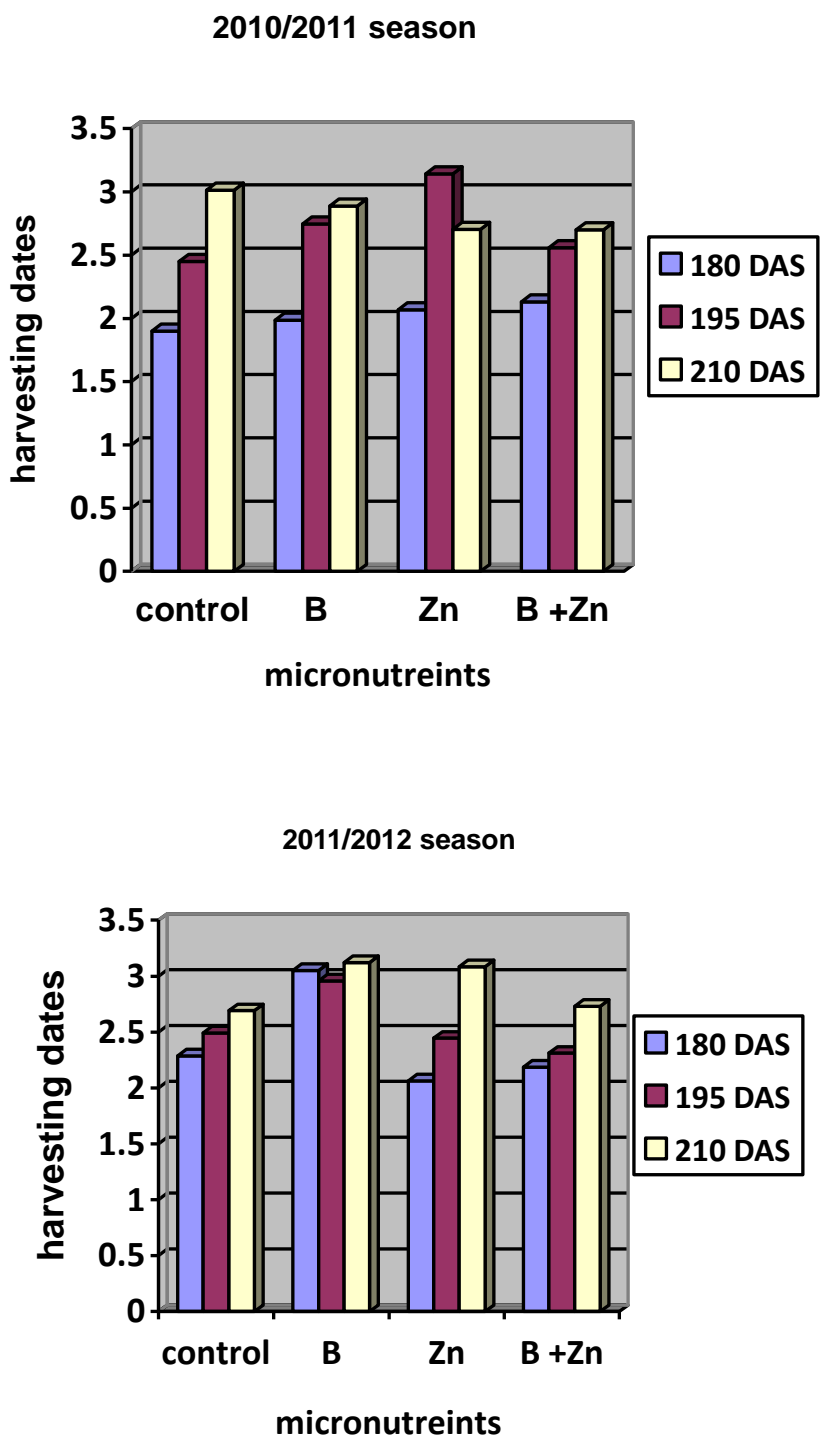

Fig. 2. Effect of the interaction between harvesting dates and micronutrients on sugar yield (ton/ fed) of sugar beet in 2010/ 2011 and 2011/ 2012 seasons . 
RESPONSE OF SOME SUGAR BEET VARIETIES ...

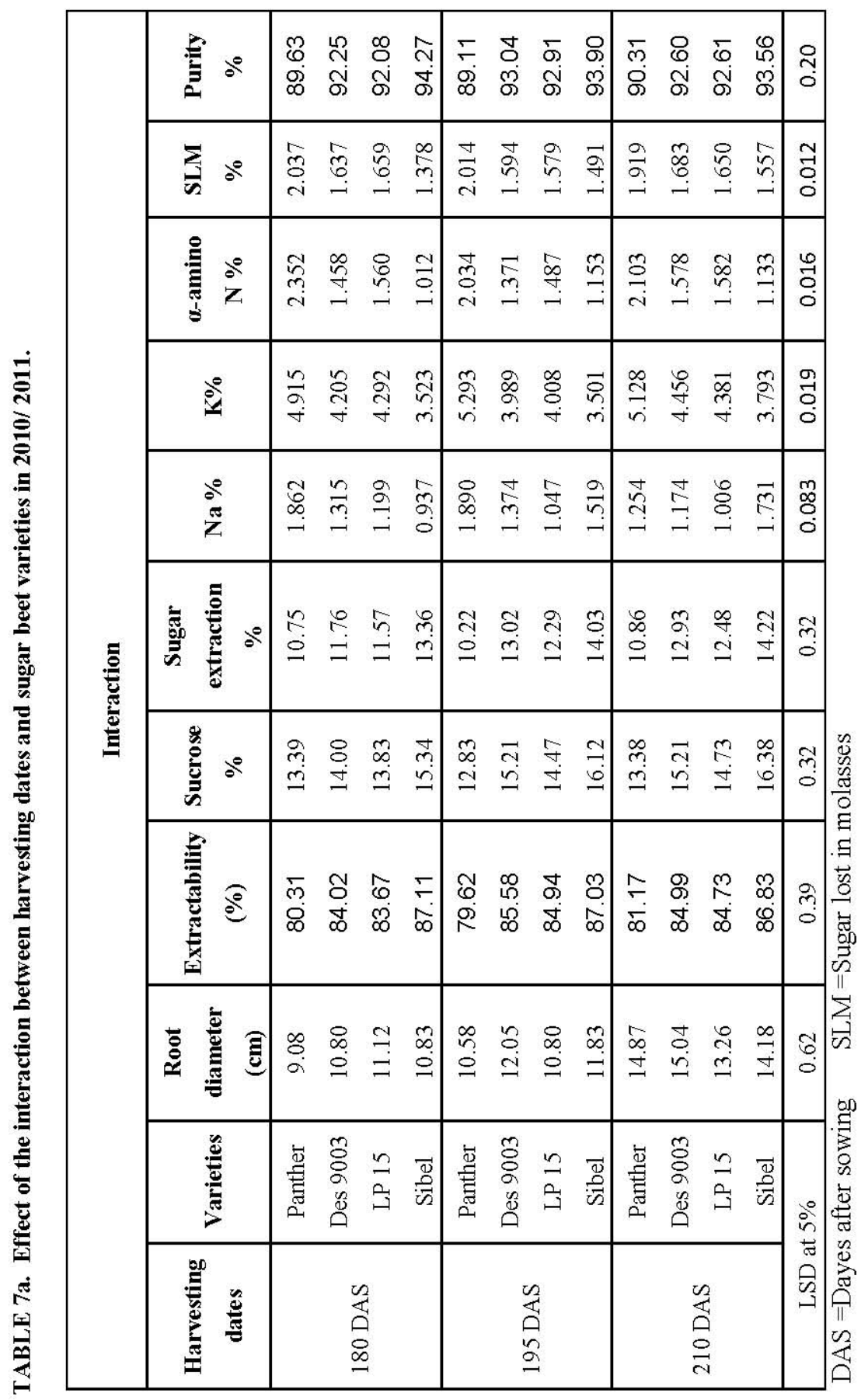

Egypt. J. Agron. 35, No. 2 (2013) 


\begin{tabular}{|c|c|c|c|c|c|}
\hline \multirow{11}{*}{ 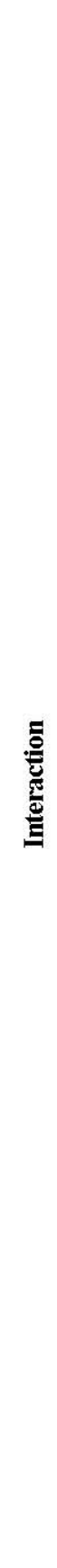 } & 量 & 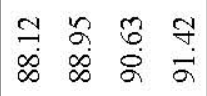 & 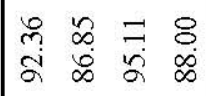 & 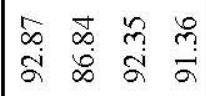 & 产 \\
\hline & $\sum_{n}^{\circ}$ & 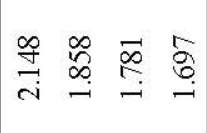 & 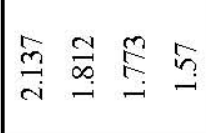 & 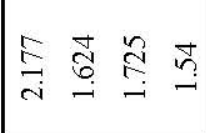 & $\mid \begin{array}{l}1 \\
8 \\
0\end{array}$ \\
\hline & 产 & 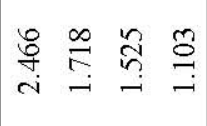 & 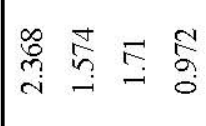 & 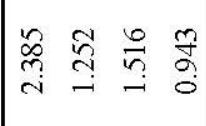 & $\mid \begin{array}{l}m \\
\vdots \\
0\end{array}$ \\
\hline & ปั & 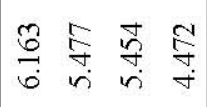 & 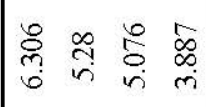 & 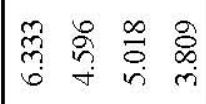 & $\mid \begin{array}{l}m \\
0 \\
0 \\
0\end{array}$ \\
\hline & 兑 & 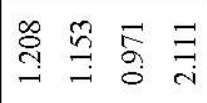 & 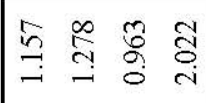 & 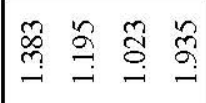 & $\mid \begin{array}{l}2 \\
\vdots \\
0 \\
0\end{array}$ \\
\hline & 勇 & 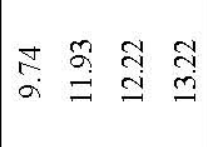 & 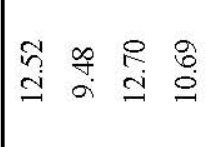 & 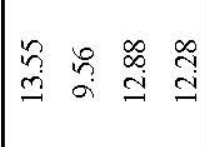 & $\vec{\square}$ \\
\hline & $\frac{1}{0}$ & 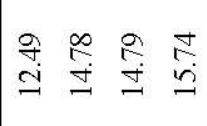 & 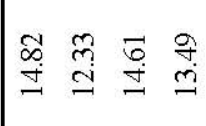 & 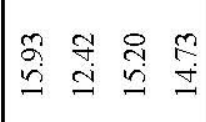 & $\underset{0}{\square}$ \\
\hline & 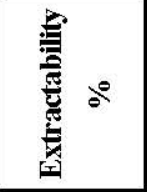 & 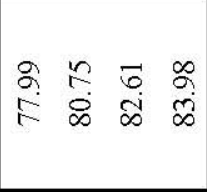 & 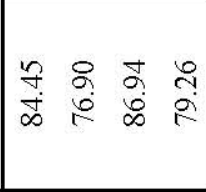 & 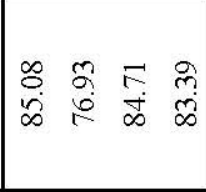 & $\frac{2}{0}$ \\
\hline & 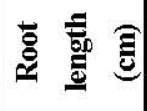 & 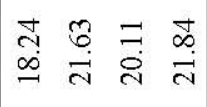 & 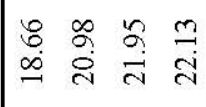 & 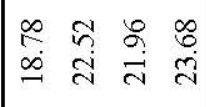 & $\mid \begin{array}{l}2 \\
0\end{array}$ \\
\hline & 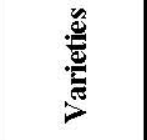 & 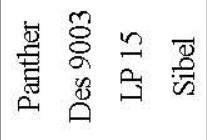 & 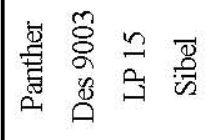 & 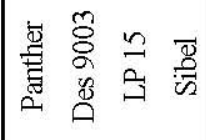 & iे \\
\hline & 遦 & 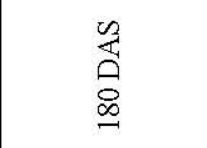 & 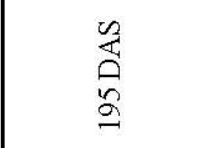 & $\begin{array}{l}\text { 足 } \\
\text { 今े } \\
\text { त }\end{array}$ & 昂 \\
\hline
\end{tabular}

Egypt. J. Agron. 35, No. 2 (2013) 


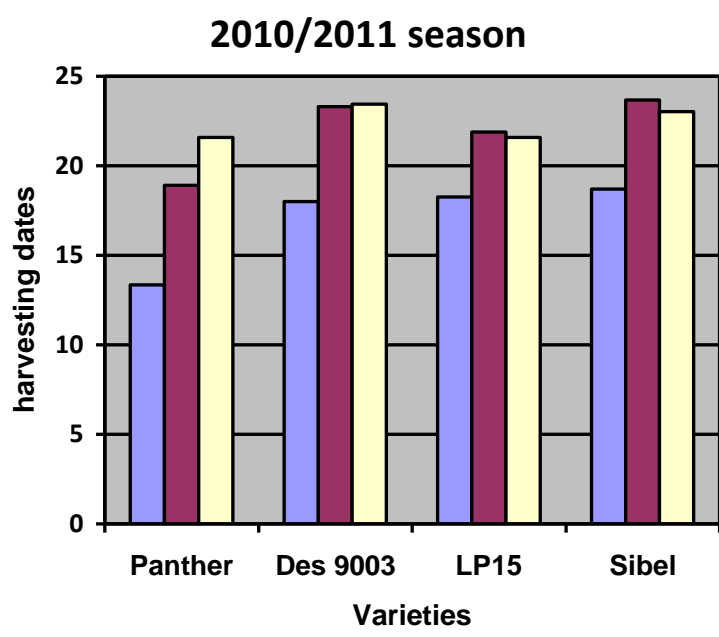

$\square 180$ DAS $\square 195$ DAS $\square 210$ DAS

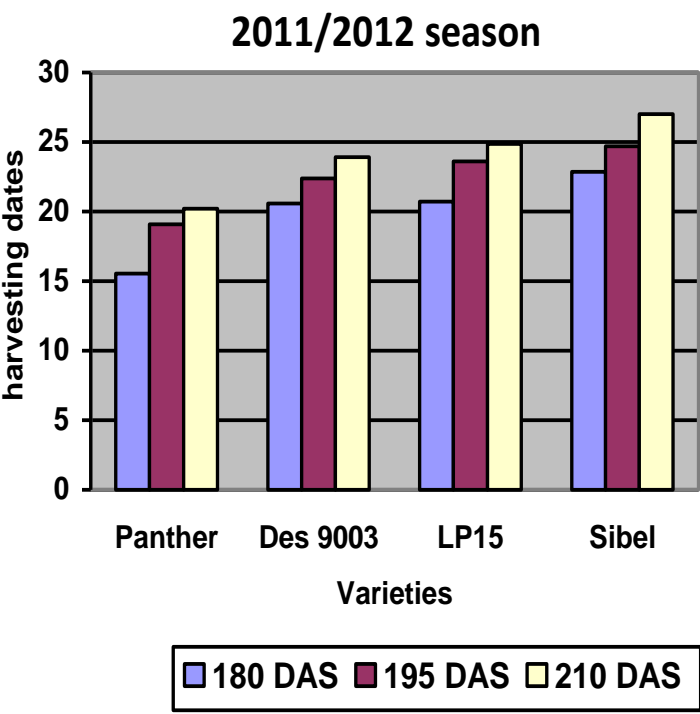

Fig. 3.Effect of the interaction between harvesting dates and varieties on root yield (ton/ fed) of sugar beet in 2010/ 2011 and 2011/ 2012 seasons . 

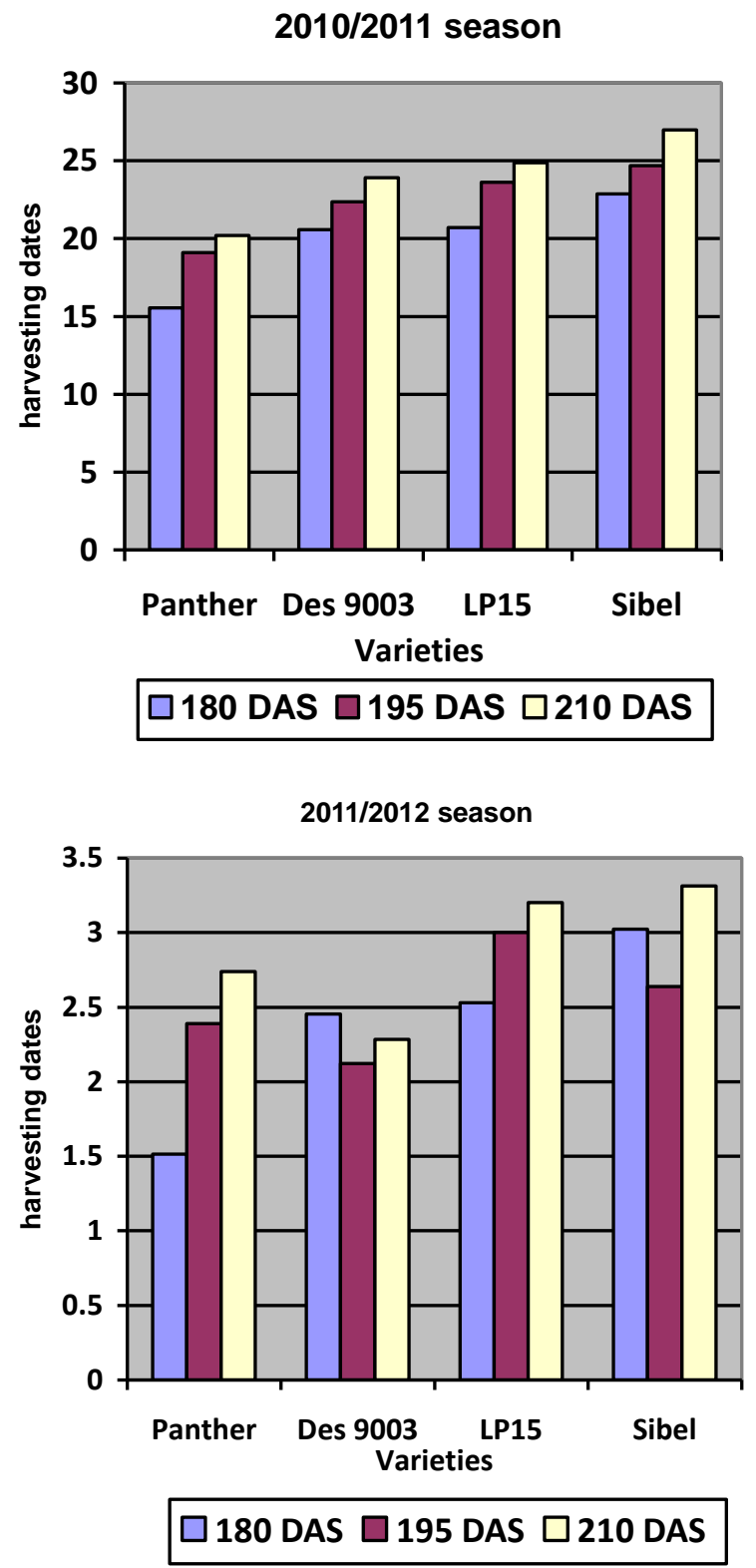

Fig. 4. Effect of the interaction between harvesting dates and varieties on sugar yield (ton/ fed) of sugar beet in 2010/ 2011 and 2011/ 2012 seasons . 


\begin{tabular}{|c|c|c|c|c|c|c|}
\hline \multirow{12}{*}{ 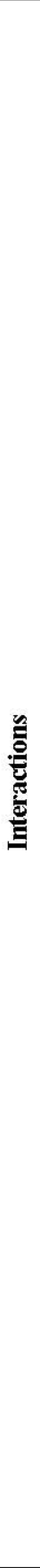 } & 害 & 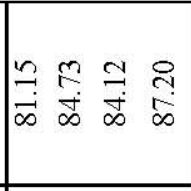 & 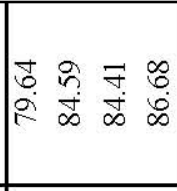 & 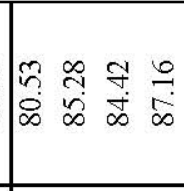 & 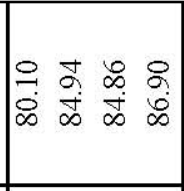 & 年 \\
\hline & 量。 & 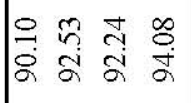 & 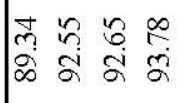 & 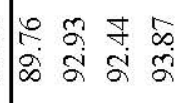 & 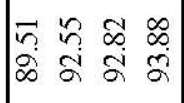 & సิ \\
\hline & $\sum_{\bar{\sigma}}^{\infty}$ & 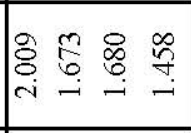 & 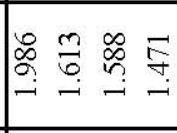 & 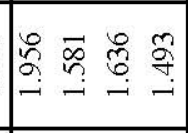 & 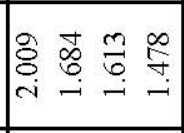 & $\begin{array}{l} \\
\\
0 \\
\end{array}$ \\
\hline & 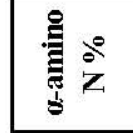 & 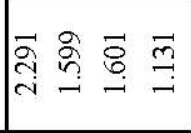 & 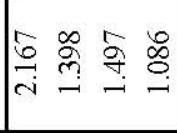 & જે & 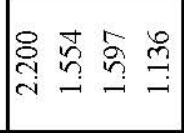 & 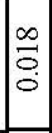 \\
\hline & $\stackrel{1}{0}$ & 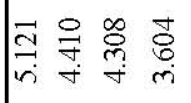 & 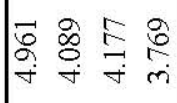 & 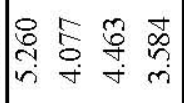 & 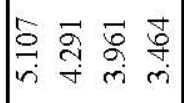 & 芯 \\
\hline & $\begin{array}{l}0 \\
\text { zo } \\
\end{array}$ & 总 き & 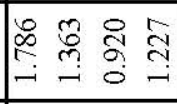 & 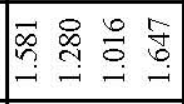 & 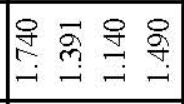 & : \\
\hline & 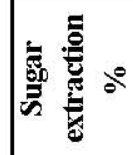 & 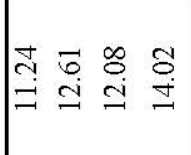 & 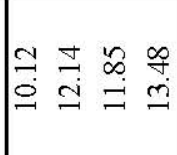 & 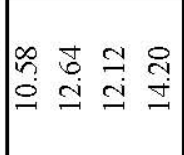 & 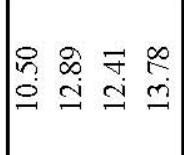 & के. \\
\hline & 密 & 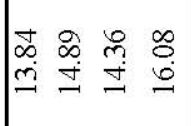 & 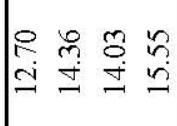 & 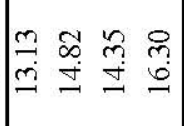 & 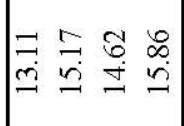 & लें \\
\hline & 递 & 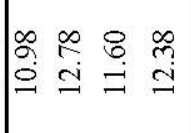 & 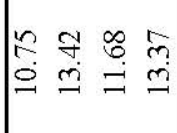 & 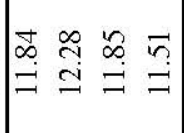 & 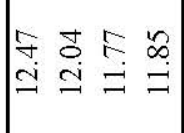 & $\stackrel{0}{\infty}$ \\
\hline & 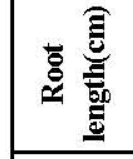 & 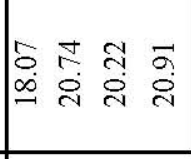 & 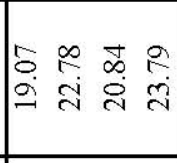 & 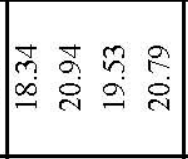 & 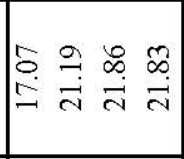 & $\mid \begin{array}{l}\infty \\
2 \\
0\end{array}$ \\
\hline & 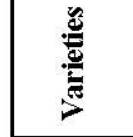 & 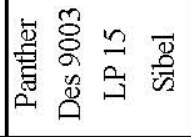 & 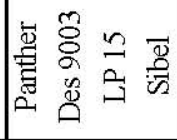 & 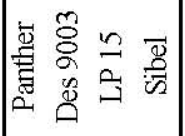 & 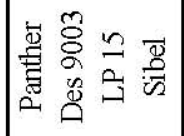 & is \\
\hline & 曾产 & 宽 & ๓ & 고 & 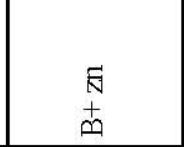 & \\
\hline
\end{tabular}




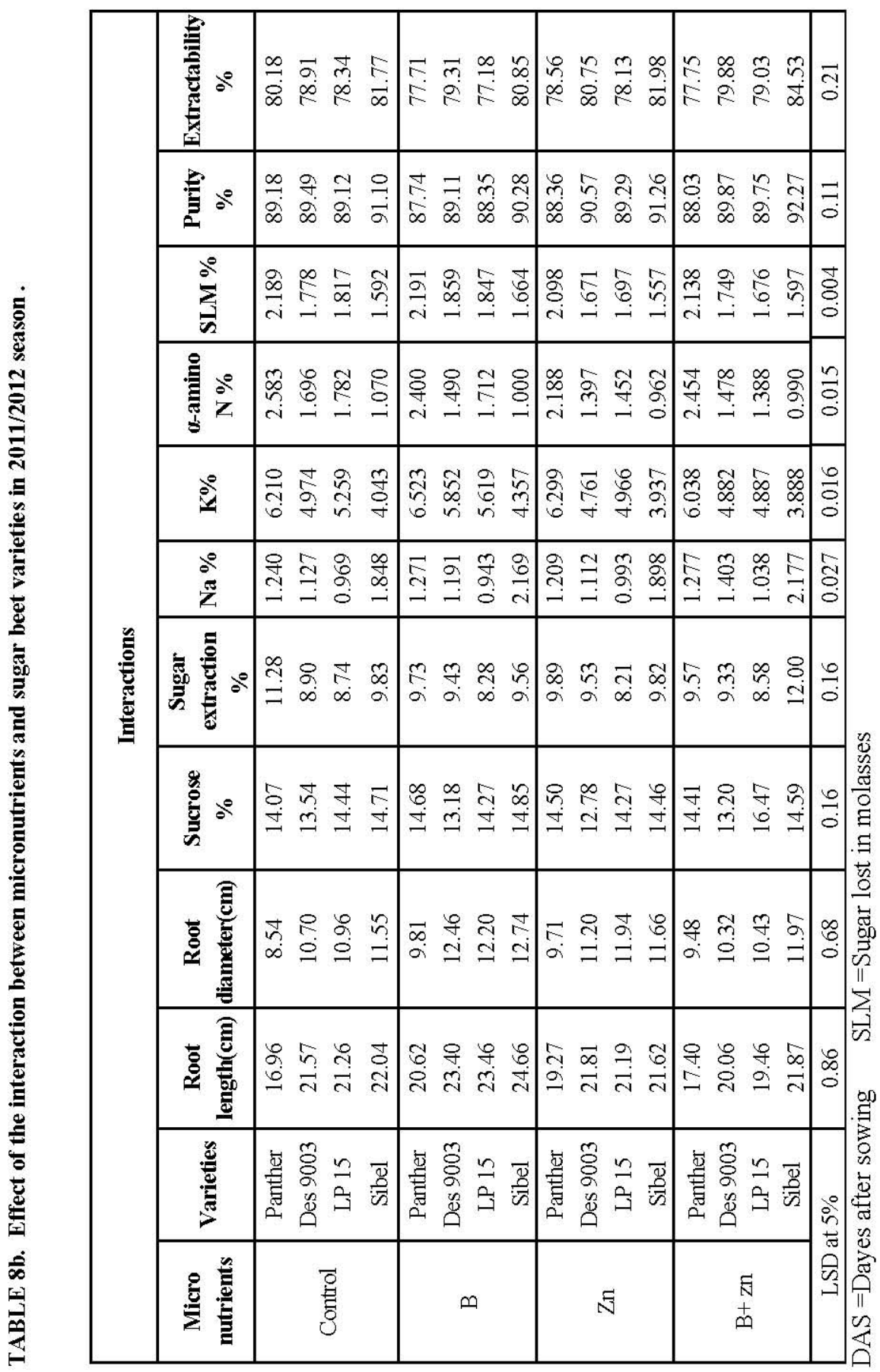

Egypt. J. Agron. 35, No. 2 (2013) 


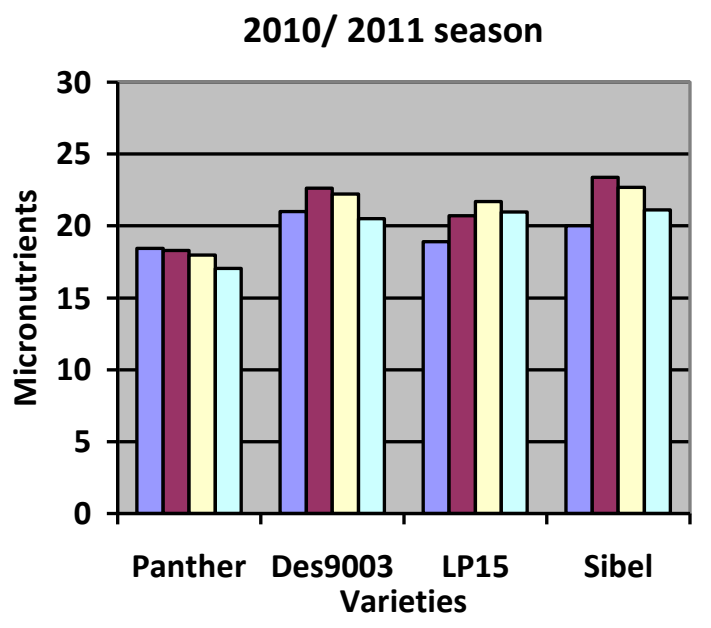

$\square$ Control $\square B \square Z n \square B+Z n$

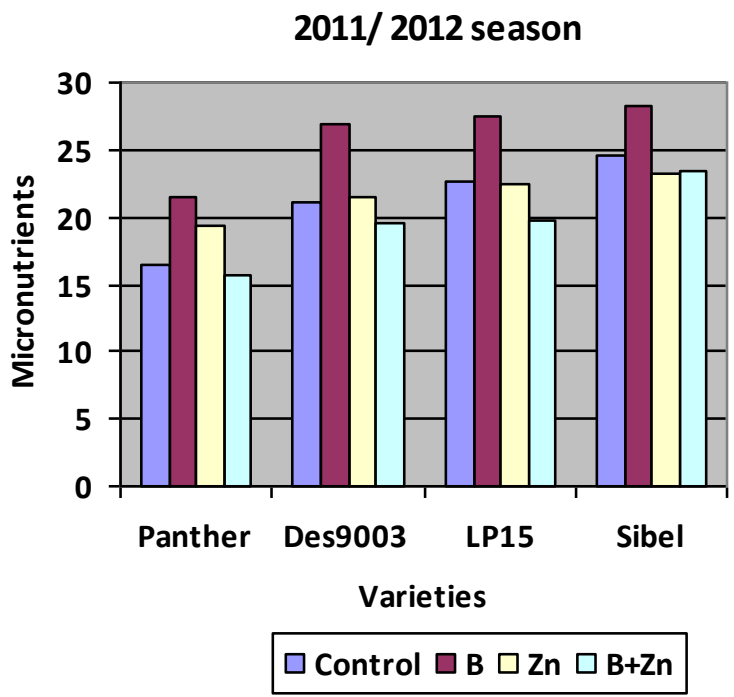

Fig. 5. Effect of the interaction between sugar beet varieties and micronutrients on root yield (ton/ fed) in 2010/ 2011 and 2011/ 2012 seasons . 


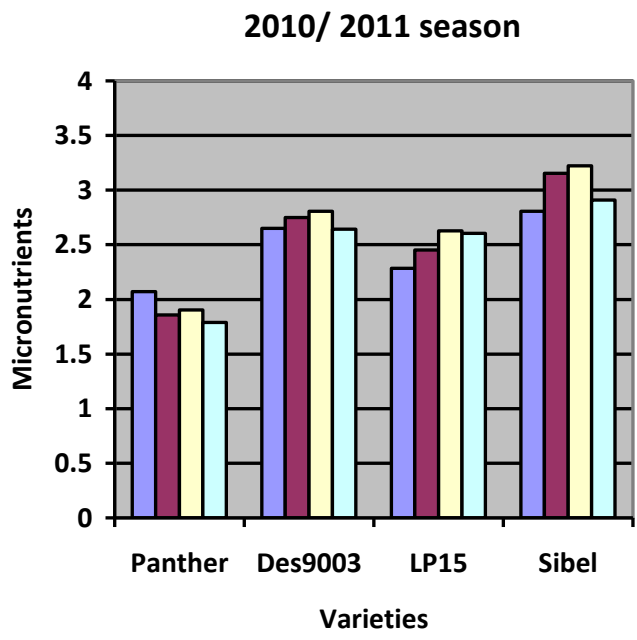

$\square$ Control $\square \mathrm{B} \square \mathrm{Zn} \square \mathrm{B}+\mathrm{Zn}$

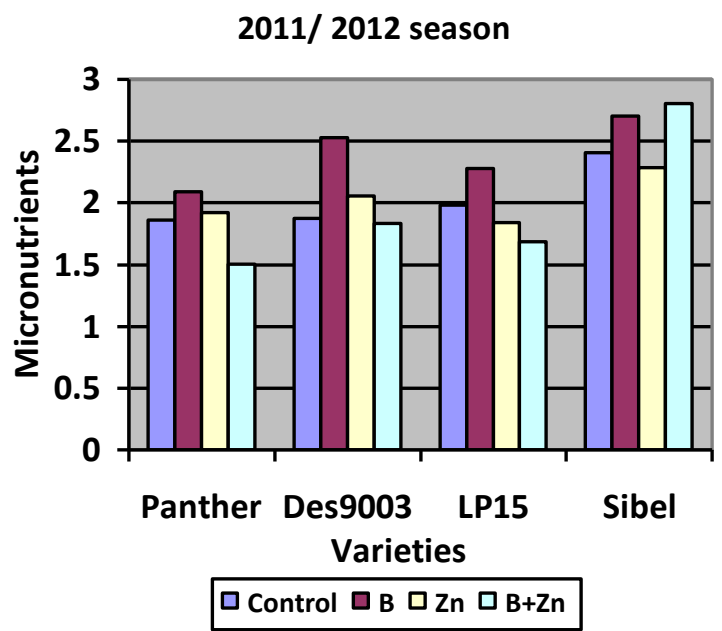

Fig. 6. Effect of the interaction between sugar beet varieties and micronutrients on sugar yield (ton/ fed) in 2010/ 2011 and 2011/ 2012 seasons . 
Effect of the interaction between harvesting dates, sugar beet varieties and micronutrients

The effects of harvesting dates and applications of micronutrients $\mathrm{Zn}$ and $\mathrm{B}$ individually or in mixture were insignificant for all studied traits in the four sugar beet varieties.

\section{References}

Abd El-Aal, A. M., Nafie, A. I. and Abdel Aziz, Ranya M. (2010) Response of some sugar beet genotypes to nitrogen fertilization under newly reclaimed land conditions. Egypt. J. Appl. Sci. 25 (6B) 194-208.

Abd El-Razek, A.M. (2006) Response of sugar beet to planting date and number of days to harvest under North Sinai conditions. Egypt. J. Agric. Res. 84 (3).

Abo EL-Hamd, A. S. and Esmail, A. A. (2008) Effect of foliar potassium, magnesium and boron on yield and quality of sugar beet (Beta vulgaris, L.) growing in new reclaimed soils. J. Agric. Sci. Mansoura Univ. 33, 1737-1746.

Allen, V. B. and Pilbeam, D.J. (2007) "Hand Book of Plant Nutrition". (Books in Soils, plants and the environment). Boron by Umesh C. Gpta. (pp. 241-278).

Al-Mohamad, H. and Al- Geddawy, S. (2001) Effect of boron on heart rot and on yield of sugar beet . Arab. J. plant Prot.19, 45-48

Al-Sayed, M.H., Abd El-Razek, U.A., Sarhan, H.M. and Fateh, H.S. (2012) Effect of harvest dates on yield and quality of sugar beet varierties. Australian Journal of Basic and Applied Sciences, 6(9), 525-529.

Alloway, B. J. (2008) "Zinc in soils and Crop Nutrition" . IZA and IFA.Brussels, Belgium and Paris, France.

Aly, E. F. (2006) Effect of environmental conditions on productivity and quality of some sugar beet varieties. Ph. D. Thesis. Fac. of Agric. Benha Univ. Egypt.

Armin , M. and Asgharipour, M. (2012) Effect of time and concentration of boron foliar application on yield and quality of sugar beet. American-Eurasian J. Agric. Environ. Sci. 12 (4), 444-448

Azzazy, N. B., Shalaby, N. M. S. and Abd El Razek, A. M. (2007) Effect of planting density and days to harvest on yield and quality of some sugar beet varieties under fayoum condition. Egypt J. Appl. Sci. 22 (12A), 101-114.

A.O.A.C. (2005) Association of Official Analytical Chemists. "Official Methods of Analysis", $16^{\text {th }}$ ed. International Washington, D.C. USA

Carruthers, A., Oldfield, J.F.T. and Teague, H.J. (1962) Assessment of beet quality. The $15^{\text {th }}$ Annual Technical Conference, British Sugar Corporation LTD.36PP. 
Cook, D.A. and Scott, R.K. (1993) "The Sugar Beet Crop". Chapman and Hall London, pp. 262-265.

Devillers, P. (1988) Prevsion du sucre melasse. Scurries francases, 129, 190-200. ( C.F. The Sugar Beet Book)

Dexter, S.T., Frankes, M.G. and Snyder, F.W. (1967) A rapid and practical method of determining extractable while sugar as may be applied to the evaluation of agronomic practices and grower deliveries in the sugar beet industry. J. Am. Soc. Sugar beet Technol. 14, 433 - 454 .

El-Geddawy, I.H., Osman, M.S., Taha, M.G.A. and Enan, S.A.A.M. (2007) Transplanting using paper pots technique and micro-nutrition with relation to yield and its attributes of sugar beet at different planting dates. Egypt. J. Agric. Res. 85(1), 191-210.

El-Hawary, M.A. (1994) Effect of boron and zinc fertilization on growth and yield of sugar beet plants grown under different soil salinity levels. Al-Azhar. J. Agric. Res. 20 (2), 25-35.

El- Sheikh, S. R. E., Khaled, K. A. M. and Ena, S. A. A. M. (2009) Evaluation of some sugar beet varieties under three harvesting dates. J. Agric. Sci. Mansoura Univ. 34 (3), 1559-1567.

Enan, S. A. A. M. (2011) Effect of transplanting and foliar fertilization with potassium and boron on yield and quality traits of sugar beet sown under saline soil conditions. $J$. Biol. Chem. Environ. Sci. 6 (2), 525-546.

Enan, S. A. A. M., El- Sheikh, S. R. E. and Khaled, K. A. M. (2009) Evaluation of some sugar beet varieties under different levels of $\mathrm{N}$ and Mo fertilization. J. Biol. Chem. Environ. Sci. 4 (1), 345-362.

Enan, S.A.A.M., Abd El-Aal, A.M. and Shalaby, N.M.E. (2011) Yield and quality of some sugar beet varieties as affected by sowing date and harvest age. Fayoum. J. Agric. Res. Dev. 25 (2), 51-65.

Gobarah, Mirvat E. and Mekki, B. B. (2005) Influence of boron application on yield and juice quality of some sugar beet cultivars grown under saline soil conditions. $J$. Appl. Sci. Res. 1 (5), 373-379.

Halvorson, A.D. and Hartman, G.P. (1980) Response of several sugar beet cultivars to $\mathrm{N}$ fertilization: Yield and crown tissue production. Agron. J. 72, 665-669.

Halvorson, A.D., Hartman, G.P., Cole, D.F., Haby, V.A. and Baldridge, D.E. (1978) Effect of $\mathrm{N}$ fertilization on sugar beet crown tissue production and processing quality. Agron. J. 70, 876-880.

Hellal, F. A. , Taalab, A. S. and Safaa, A. M . (2009) Influence of nitrogen and boron nutrition on nutrient balance and sugar beet yield grown in calcareous soil. Ozean Journal of Applied Sciences, 2(1).

Egypt. J. Agron. 35, No. 2 (2013) 


\section{Hemphill, D. D.(1982) Soil Sci. Am. J. 46, 1190-1192}

Kristek, A., Bisekastojic and Suzana Kristek (2006) The effect of foliar boron fertilizer on sugar beet root yield and quality. Agric. Sci. and Proffessional Rev. 12(1).

Le Docte, A. (1927) Commercial determination of sugar in beet root using the Sacks. Le Docte process. Int. Sugar J. 29, 488-492.

Mahmoud, S.A., Hasanin, B., El-Geddawy, I.H. and Mosa, D.T.A. (2008) Effect of sowing and harvesting dates on yield and quality of some sugar beet varieties. Proc. Inter. Conf. (IS-2008) Al-Arish, Egypt. Sept. 11-14, pp. 22-29.

Mohammed, A. and Asghharipour, M. R. (2011) Effect of time and concentration of boron foliar application on yield and quality of sugar beet. Asian J. Plant Sci. 10(5), 307-311.

Mohamed, Kh. El-Sh., Mohamed, Hanan Y. and Abdel Fatah, E.M. (2012) Effect of nitrogen sources fertilization and boron foliar application on growth, quality and productivity of some sugar beet varieties. J. Biol. Chem. Environ. Sci. 7(4), 177-192.

Moustafa, Zeinab R., Soudi, Amal M. K. and Khalil El - Shenawy, M. (2011) Productivity and quality of sugar beet as influenced by nitrogen fertilizer and some micronutrients. Egypt. J. Agric. Res. 89 (3), 1005-1018.

Mousavi Roholla, S., Mohammed, G. and Maryam, R. (2013) Zinc importance for crop production . Intl. J. Agron. Plant. Prod. 4(1),64-68.

Osman, A. M. H., El-Sayed, G. S., Osman, M.S.H. and El-Sogheir, K. S. (2003) Soil application of some microelements with relation to yield and quality of sugar beet varieties. Annals of Agric. Sci., Moshtohor, 41 (3), 1071-1088.

Page, A. L. (1982) "Methods of Soil Analysis". Chemical and Microbiological Properties. $2^{\text {nd }}$ ed., Agron. 9, Am. Soc. Agron. Inc. Publ. Madison, Wis, USA.

Shen, Z., Liang, Y. and Shen, K. (1993) Effect of boron on the nitrate reductase activity in oilseed rape plants. J. Plant Nutr. 16, 1229-1239.

Snedecor, G. W. and Cochran, W. G. (1981) "Statistical Methods" $6^{\text {th }}$ ed. Iowa State Univ. Press, Ames, Iowa, USA.

Stevens,W.B. and Mesbah, A.O. (2004) Zinc enhances sugar beet emergence and yield on a calcareous soil with marginal zinc availability. Crop Management DOI:,10, 1094/ CM.

Tyksinski, W. (1993) Response of green house lettuce to differentiated micronutrients fertilization. VI. Interaction between microelements News and Information. A quarterly publication. 16 (1), 45, 1996.

Yousef, M.S.H. and Abdel - Mottaleb, H.M. (2009) Effect of sowing and harvesting dates on productivity of some sugar beet varieties under Sinai conditions. J. Agric. Sci. Mansoura Univ. 34 (9), $9543-9556$.

(Received 20/1/2014; accepted $11 / 3 / 2014)$ 


\section{استجابة بعض اصناف بنجر السكر لمواعيد الحصاد والرش الرض الرئ بالبورون والزنك في الاراضى الرملية \\ حنان يوسف محمد و محمد عبدالسلام طه ياسين"

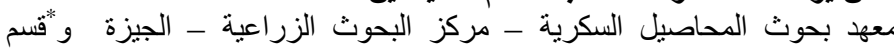

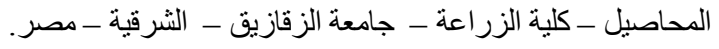

اجريت تجربتان حقليتان فى المزرعة التجريبية التابعة لكلية الزراعة - جامعة

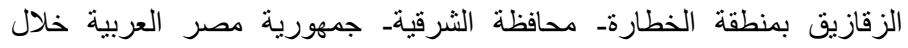

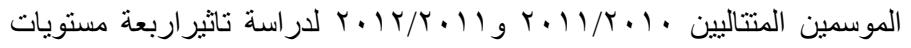

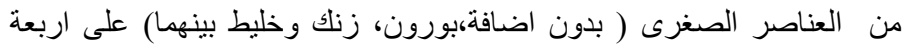

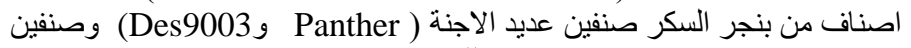

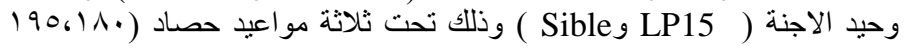

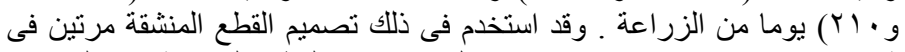

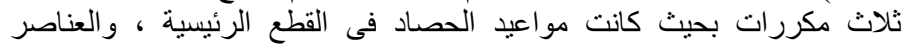

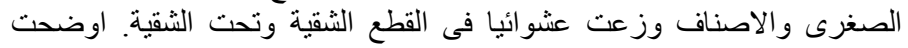

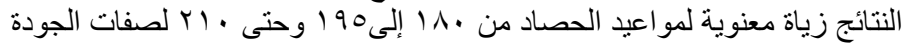

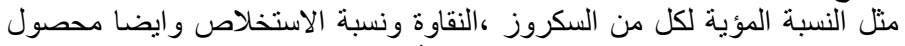

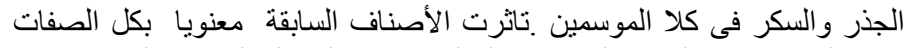

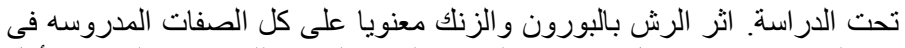

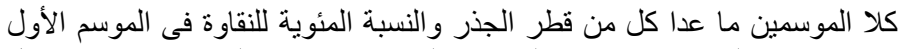

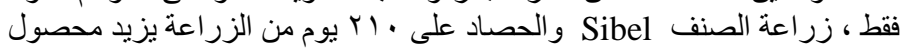

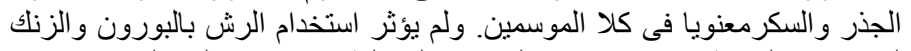

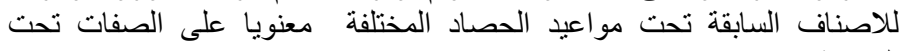
الار اسة. 